\title{
Downdraught assessment during design: Experimental and numerical evaluation of a rule of thumb
}

Citation for published version (APA):

Schellen, L., Timmers, S., Loomans, M., Nelissen, E., Hensen, J. L. M., \& van Marken Lichtenbelt, W. D. (2012). Downdraught assessment during design: Experimental and numerical evaluation of a rule of thumb. Building and Environment, 57, 290-301. https://doi.org/10.1016/j.buildenv.2012.04.011

Document status and date:

Published: 01/01/2012

DOI:

10.1016/j.buildenv.2012.04.011

Document Version:

Publisher's PDF, also known as Version of record

Document license:

Taverne

Please check the document version of this publication:

- A submitted manuscript is the version of the article upon submission and before peer-review. There can be important differences between the submitted version and the official published version of record.

People interested in the research are advised to contact the author for the final version of the publication, or visit the DOI to the publisher's website.

- The final author version and the galley proof are versions of the publication after peer review.

- The final published version features the final layout of the paper including the volume, issue and page numbers.

Link to publication

\footnotetext{
General rights rights.

- You may freely distribute the URL identifying the publication in the public portal. please follow below link for the End User Agreement:

www.umlib.nl/taverne-license

Take down policy

If you believe that this document breaches copyright please contact us at:

repository@maastrichtuniversity.nl

providing details and we will investigate your claim.
}

Copyright and moral rights for the publications made accessible in the public portal are retained by the authors and/or other copyright owners and it is a condition of accessing publications that users recognise and abide by the legal requirements associated with these

- Users may download and print one copy of any publication from the public portal for the purpose of private study or research.

- You may not further distribute the material or use it for any profit-making activity or commercial gain

If the publication is distributed under the terms of Article $25 \mathrm{fa}$ of the Dutch Copyright Act, indicated by the "Taverne" license above, 


\title{
Downdraught assessment during design: Experimental and numerical evaluation of a rule of thumb
}

\author{
L. Schellen $^{\mathrm{a}, *}$, S. Timmers ${ }^{\mathrm{a}}$, M. Loomans ${ }^{\mathrm{a}}$, E. Nelissen ${ }^{\mathrm{a}}$, J.L.M. Hensen ${ }^{\mathrm{a}}$, W. van Marken Lichtenbelt ${ }^{\mathrm{b}}$ \\ a Department of the Built Environment, Unit Building Physics and Services, Eindhoven University of Technology, Eindhoven, P.O. Box 513, 5600 MB Eindhoven, The Netherlands \\ ${ }^{\mathrm{b}}$ Department of Human Biology, NUTRIM School for Nutrition, Toxicology and Metabolism of Maastricht University Medical Center+, P.O. Box 616, 6200 MD Maastricht, \\ The Netherlands
}

\section{A R T I C L E I N F O}

\section{Article history:}

Received 10 January 2012

Received in revised form

29 March 2012

Accepted 12 April 2012

\section{Keywords:}

Downdraught

Rule of thumb

Glazed façades

Thermal comfort

Subjective responses

Computational fluid dynamics (CFD)

\begin{abstract}
A B S T R A C T
Large glass façades are popular architectural features in building design nowadays. However, these façades can result in interior downdraught during periods with low outdoor temperatures. A rule of thumb exists to assess the downdraught risk, based on window height and window temperature [1]. In this paper the validity of this rule of thumb is evaluated by an experimental and a numerical study.

In the experimental part ten healthy male subjects (age 20-26 year) are exposed to two different downdraught conditions in a controlled climate chamber. Experimental results are also used to validate the numerical models. In the numerical (Computational Fluid Dynamics) part a parameter study has been performed to assess the influence of window height and window surface temperature beyond the range tested in the climate chamber. In addition, different floor temperatures have been investigated to evaluate the effect of floor heating as a possible design option to prevent downdraught.

Based on both experimental and numerical results the existing rule of thumb is shown to be conservative. Furthermore, the numerical results reveal that an increased floor temperature (i.e. floor heating) can increase the downdraught risk. Therefore, it is recommended to modify the rule of thumb by incorporating the floor temperature as a parameter.
\end{abstract}

(c) 2012 Elsevier Ltd. All rights reserved.

\section{Introduction}

Glazed façades and atria are popular architectural building design features. These features are regarded as beneficial measures in terms of daylight. However, these façades may cause comfort related problems due to downdraught. In case of downdraught the air layer close to a cold surface (i.e. window) is cooled, which causes this layer to flow downwards due to buoyant forces. In this paper the term 'downdraught' is used for this type of buoyancy driven flows.

If the cold air flow is not compensated for by an upstream air flow, the cold air can penetrate into the living zone [2]. Until ten years ago downdraught related problems were mainly solved by placing heating appliances underneath glazed façades and large windows. With the improvement of the thermal performance of windows and window systems since, additional heating appliances may not be necessary anymore [3-7]. However, in current building practice often a cautious approach is taken. Therefore, radiators,

\footnotetext{
* Corresponding author. Tel.: +310 40247 4834; fax: +310 402438595 .

E-mail address: 1.schellen@tue.nl (L. Schellen).
}

convectors or floor heating systems are installed beneath windows while they might not be required with respect to downdraught.

According to Huizenga et al. [4] two aspects are important regarding a glazed façade in relation to thermal comfort: cold radiant asymmetry and draught. Radiant asymmetry is influenced by the surface temperature of the window, posture and position of the subject and human factors like clothing level and metabolism. Draught is affected by the air velocity, turbulence intensity and air temperature.

Several numerical and experimental studies have been conducted to improve understanding of the flow principle and the effect of several solutions to prevent downdraught. Heiselberg, among others, concluded that windows up to $2.5 \mathrm{~m}$ height do not cause downdraught related problems in case of well-insulated glazing systems (expressed by a maximum temperature difference between the room air and the window surface of $2.5^{\circ} \mathrm{C}$ ) with the occupied zone starting at $0.6 \mathrm{~m}$ from the window [2].

To assess the risk of downdraught in the design phase several rules of thumb are available. Olesen, among others, defined a rule of thumb that allows assessment of the maximum window height $(h$ in $\mathrm{m})$ in combination with the $U$-value of the glazing $\left(U_{\text {glass }}\right.$ in $\left.\mathrm{W} / \mathrm{m}^{2} \mathrm{~K}\right)$ with given constraints on the maximum accepted air velocity $\left(v_{\text {air }}\right.$ in 
$\mathrm{m} / \mathrm{s}$ ) in the living area (Equation (1)) [1]. If a lower maximum accepted air velocity is considered, equation (2) can be applied [8].

$$
\begin{aligned}
& U_{\text {glass }} * h \leq 4.7 \mathrm{~W} / \mathrm{m} \mathrm{K} \quad v_{\text {air;max }}=0.18 \mathrm{~m} / \mathrm{s} \\
& U_{\text {glass }} * h \leq 3.2 \mathrm{~W} / \mathrm{m} \mathrm{K} \quad v_{\text {air;max }}=0.15 \mathrm{~m} / \mathrm{s}
\end{aligned}
$$

The numerical and experimental studies from which the rule of thumb has been derived, show some limitations: - Only draught is taken into account, while according to Huizenga et al. [4] radiation also has a significant influence on thermal comfort related to downdraught; - The results are not validated in experiments with human subjects; - In most studies the window height is limited to two or $3 \mathrm{~m}$, while it is expected that frequently installed higher windows cause more problems related to thermal comfort.

As this particular rule of thumb is still applied in practice, the question is to what extent it is able to predict the downdraught risk correctly. As the rule of thumb also does not address contemporary counteracting design solutions, the query arises whether lowtemperature heating systems (e.g. floor heating) are able to prevent downdraught.

Following the above, the objective of this study is to validate the presented rule of thumb in an experimental study with human subjects and evaluate its applicability for high windows and configurations with floor heating.

The research method applied experiments with human volunteers in a climate chamber and numerical modelling with Computational Fluid Dynamics (CFD) to evaluate alternative configurations. The experiments with the human volunteers were designed $a$ priori. Since, the configuration of the climate chamber did not allowed an evaluation of the downdraught risk with respect to the window height, a numerical study was performed to analyse the effects of the window height. The numerical model is validated against experimental results obtained under the same conditions as the subjects were exposed to.

First, the experimental facility (Section 2) is described. In this facility both subject experiments and measurements to validate the numerical model have been conducted. Description and results of the subject experiments are presented and discussed in Section 3. CFD model details and verification are described in Section 4. In Section 5 the variant study to investigate different downdraught configurations is presented and discussed. In Section 6 conclusions from the experimental and numerical study are discussed with respect to the objective of the study. The paper ends with conclusions and implications for building practice and topics for future work (Section 7).

\section{Experimental facility}

Both the experiments with human subjects and the experiments for validation of the CFD model were carried out in a climate chamber (thermophysiological test room, Fig. 1). The test room is situated at the laboratory of the unit Building Physics and Services of the department of the Built Environment at the Eindhoven University of Technology. The dimensions of the room are similar to a standard office room: $3.6 \times 5.4 \times 2.7 \mathrm{~m}^{3}(\mathrm{~W} \times \mathrm{L} \times \mathrm{H})$. The test room is constructed of a well-insulated chamber (wall thickness is $100 \mathrm{~mm}$ ). In this chamber the temperature of each surface can be controlled individually in the range of $11-35^{\circ} \mathrm{C}$ [9]. Cooling of these panels is possible through a connection to an aquifer system and ranges between 10 and $17{ }^{\circ} \mathrm{C}$. For heating, a boiler in combination with a supplementary electrical heater for fine-tuning the supplied water temperature is applied. The total temperature range of the supplied water is $11-35^{\circ} \mathrm{C}$.

The air was conditioned by an air-handling unit (Verhulst); the ventilation rate was $150 \mathrm{~m}^{3} / \mathrm{h}$. Supply was through a slit $(0.01 \mathrm{~m}$
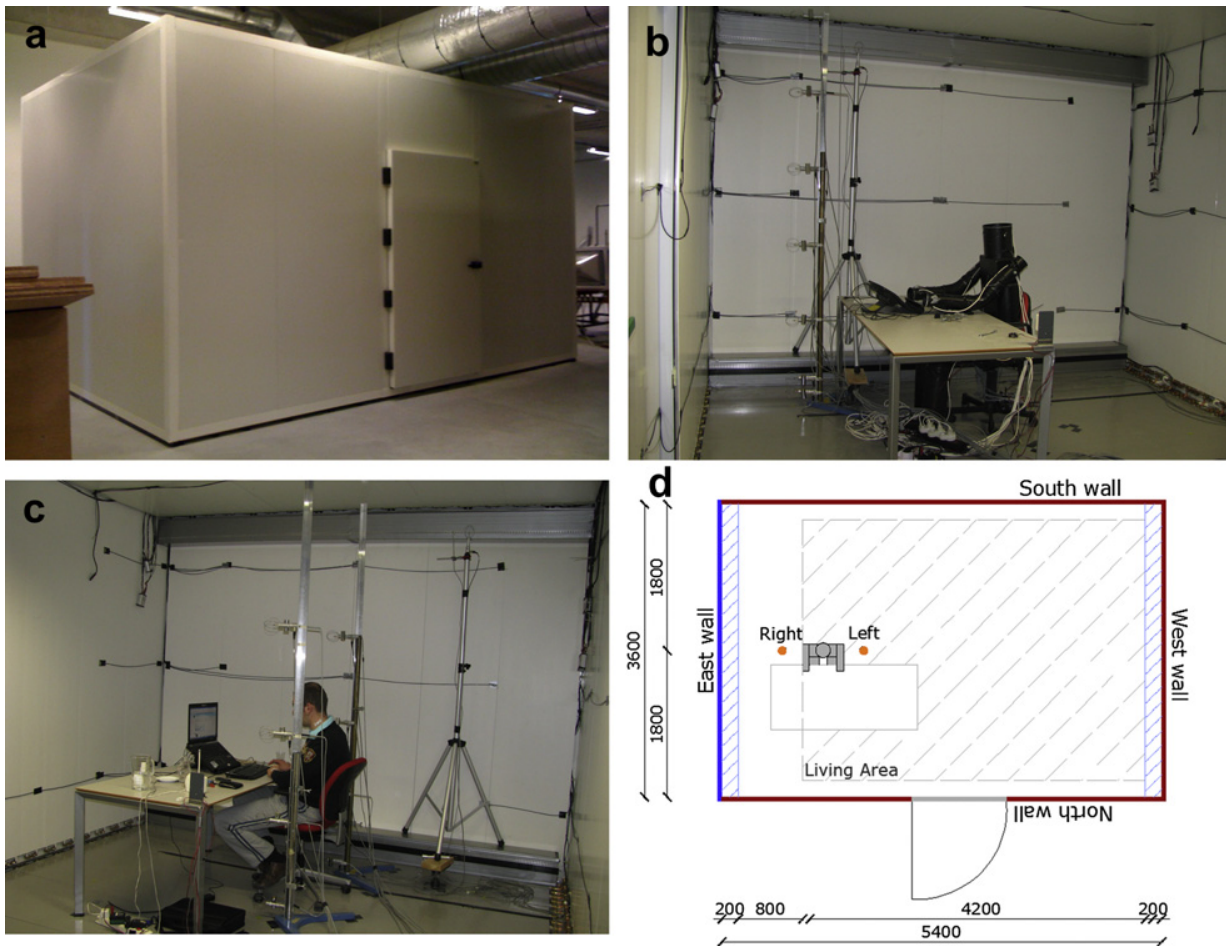

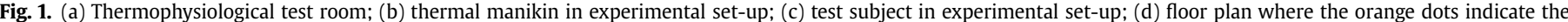

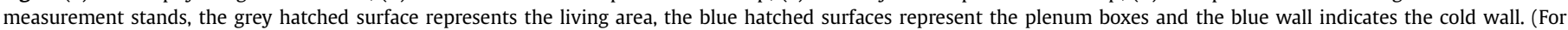
interpretation of the references to colour in this figure legend, the reader is referred to the web version of this article). 
height) along the width of the room, integrated in a plenum box $\left(100 \times 3600 \times 200 \mathrm{~mm}^{3} \mathrm{~W} \times \mathrm{L} \times \mathrm{H}\right)$ positioned at the top of the smallest wall. The exhaust $(0.2 \mathrm{~m}$ height $)$ was positioned in a similar box at the top of the opposite wall. Temperature control for air and water was provided through an embedded system (software programmed in LabView 8.6, National Instruments, Austin, USA).

\section{Subject experiments}

This section describes the subject experiments in order to evaluate the applicability of the rule of thumb (Eqs. (1) and (2)). In total two cases have been investigated.

\subsection{Method}

\subsubsection{Configuration and equipments}

During the experiments both physical and physiological measurements have been performed continuously. Air temperature (NTC Thermistor, type SC95, accuracy $\pm 0.1{ }^{\circ} \mathrm{C}$ ), relative humidity (RH) (Humidity Sensors, Honeywell HIH- 4000 series), air velocity (hot sphere anemometer, Dantec, estimated accuracy 15\% [10]), surface temperature (NTC Thermistor, U-type EU-UU-10-PTFE, accuracy $\pm 0.1{ }^{\circ} \mathrm{C}$ ) carbon dioxide (Carbon Dioxide Transmitter, Vaisala 0-2000 ppm), and illuminance (Lux meter, Hager model E2) were measured according to NEN-EN-ISO 7726 [11]. Air temperature, $\mathrm{RH}$, and air velocity were measured on two stands at $0.1,0.6,1.1$ and $1.7 \mathrm{~m}$ height. These stands were placed on the left and right side of the subject, at a distance of $0.2 \mathrm{~m}$ (the orange dots in Fig. 1d). The average surface temperature for each surface was derived from nine measurement points on each surface (at a grid of $3 \times 3$ ). The mean radiant temperature was determined according to the surface temperatures and view factors related to the position of the subject.

Skin temperatures were measured according to NEN-EN-ISO 9886 [12] by wireless iButtons (Thermochron iButton, DS1291H,
Maxim, CA, Sunnyvale, USA, accuracy $\pm 0.125^{\circ} \mathrm{C}$ ) at 24 locations to assess possible differences between the left and right side of the human body [13]. Ibuttons were attached with semi-permeable tape (Fixomull; BSN medical gmbh, Hamburg, Germany). Mean skin temperature was calculated according to the 14-point weighing as proposed by NEN-EN-ISO 9886 [12] (Point 1-14, Fig. 2a). Distal skin temperature was calculated as average of instep, ankle, finger tip, hand, and forehead skin temperature. To avoid a disproportional distribution, forehead and instep temperature have been taken into account twice. Proximal skin temperature was calculated as an average of the scapula, paravertebral, upper chest, and abdomen skin temperature. Core temperature was determined by measuring the intestinal temperature through an ingestible telemetry pill (CorTemp, Ingestible Core Body Temperature Sensor, HT150002, HQ Inc., Palmetto, FL, USA, accuracy $\pm 0.1^{\circ} \mathrm{C}$ ), which was ingested $30 \mathrm{~min}$ before entering the climate room.

\subsubsection{Cases}

For the subject experiments two different downdraught situations were defined. One case (S1) without compensation by a heating appliance and one case (S2) with compensation through a low temperature floor heating system. Downdraught was created by cooling the 'east wall' (Fig. 1d). The subjects were positioned at the boundary of the living area, i.e. $1 \mathrm{~m}$ from the cold wall (see Fig. 1d). This distance is adopted from NEN-EN-ISO 7730 [14], note that this distance is larger than the distance assumed by Heiselberg [2].

Both cases were designed at a mean operative temperature of $21.5{ }^{\circ} \mathrm{C}$ (S1: $21.6 \pm 0.04{ }^{\circ} \mathrm{C}$ and S2: $21.8 \pm 0.03{ }^{\circ} \mathrm{C}$ ) which corresponds to a predicted neutral thermal sensation ( $\mathrm{PMV} \approx 0$; for a clo-value of 1.0 and an activity level of 1.2 met, see 'Protocol'). The mean operative temperature of case S2 is slightly, though significant $(P<0.05)$, higher in comparison to case $S 1$. Furthermore, when the cases are assessed to the rule of thumb they would both not be allowed $\left(U_{\text {glass }}{ }^{*} h\right.$ is for S1: $5.1 \pm 0.3 \mathrm{~W} / \mathrm{mK}$ and for S2: $5.2 \pm 0.3 \mathrm{~W} / \mathrm{mK}$, maximum allowed is $4.7 \mathrm{~W} / \mathrm{mK}$ ). For this a

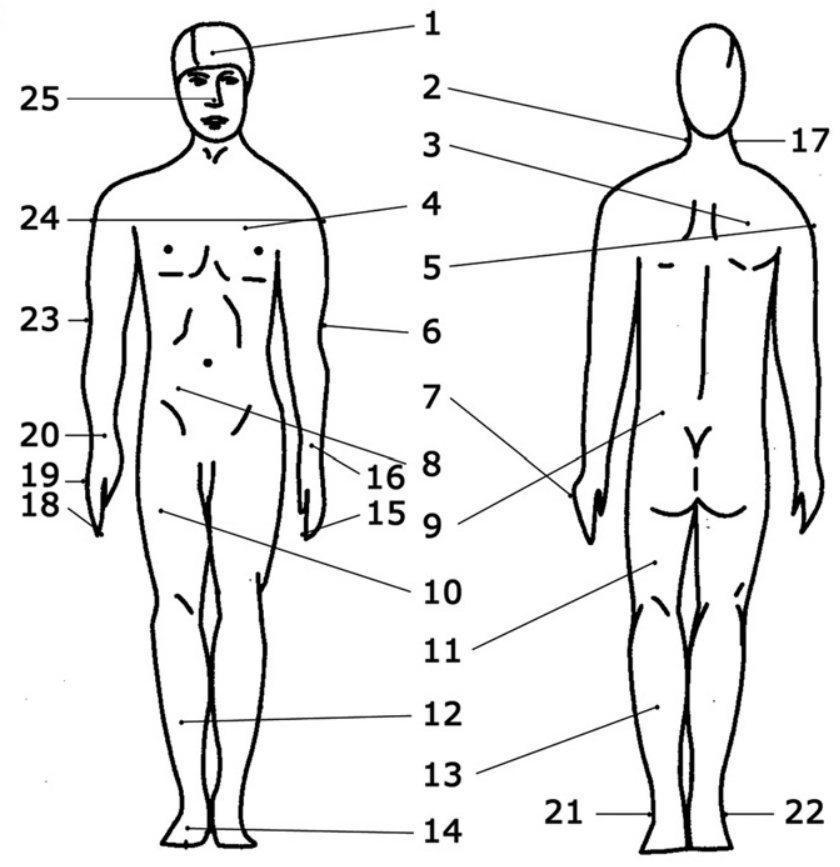

b L

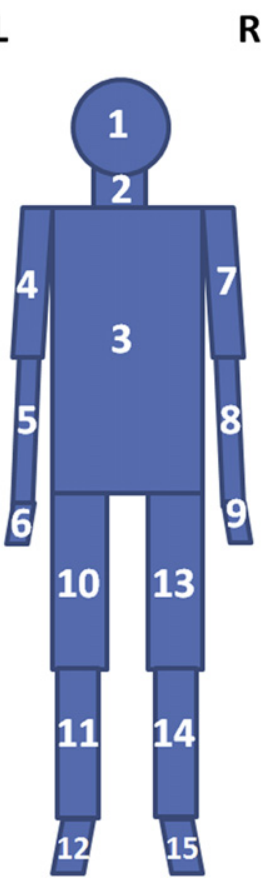

Fig. 2. (a) Measurement sites skin temperature; (b) schematic representation of body parts to assess local thermal sensation and comfort. 
Table 1

Case summary.

\begin{tabular}{lcc}
\hline & \multicolumn{1}{c}{ Case S1 } & Case S2 \\
\hline$U_{\text {glass }}{ }^{*} h[\mathrm{~W} / \mathrm{mK}]$ & $5.1 \pm 0.3$ & $5.2 \pm 0.3$ \\
Mean operative temperature $\left[{ }^{\circ} \mathrm{C}\right]$ & $21.6 \pm 0.1$ & $21.8 \pm 0.2^{*}$ \\
Mean air temperature $\left[{ }^{\circ} \mathrm{C}\right]$ & $22.1 \pm 0.1$ & $22.2 \pm 0.2$ \\
Surface temperature east wall $\left[{ }^{\circ} \mathrm{C}\right]$ & $13.7 \pm 0.4$ & $13.7 \pm 0.6$ \\
Surface temperature floor $\left[{ }^{\circ} \mathrm{C}\right]$ & $23.0 \pm 0.0$ & $24.3 \pm 0.1^{*}$ \\
Surface temperature remaining surfaces $\left[{ }^{\circ} \mathrm{C}\right]$ & $23.2 \pm 0.1$ & $22.7 \pm 0.1$ \\
Mean radiant temperature $\left[{ }^{\circ} \mathrm{C}\right]$ & $21.1 \pm 0.1$ & $21.3 \pm 0.2^{*}$ \\
Mean radiation asymmetry $\left[{ }^{\circ} \mathrm{C}\right]$ & $6.1 \pm 0.2$ & $6.1 \pm 0.3$ \\
Mean air velocity $[\mathrm{m} / \mathrm{s}]$ & $0.07 \pm 0.01$ & $0.09 \pm 0.02^{*}$ \\
Mean turbulence intensity $[\%]$ & $25.9 \pm 1.6$ & $25.9 \pm 1.3$ \\
Mean relative humidity $[\%]$ & $46.9 \pm 6.3$ & $47.7 \pm 6.0$ \\
\hline
\end{tabular}

${ }^{*}$ Significant case effect $(P<0.05)$.

assessment the maximum allowed air velocity is set at $0.18 \mathrm{~m} / \mathrm{s}$ (Equation (1)), where the $U$-value of the glass is calculated according to Equation (3), which assumes an indoor-outdoor temperature difference of $34 \mathrm{~K}$.

$U_{\text {glass }}=\frac{T_{\text {air;indoor }}-T_{\text {window }}}{4.08}$

The conditions for each case are listed in Table 1; mean operative temperature, air velocity, turbulence intensity and relative humidity were averaged from the measurement data from the two comfort stands that were applied during the measurements (Fig. 1d: 'Right' and 'Left').

\subsubsection{Subjects}

Ten young male subjects, age $18-26$ years, participated in the experiment. The volunteers were given detailed information regarding the purpose and the methods used in the study, before written consent was obtained. However, they were not informed on the actual conditions they were exposed to. All subjects were healthy, normotensive, non-obese, and not taking any medications that might alter the cardiovascular or thermoregulatory responses to the temperature changes; subject characteristics are listed in Table 2. Body fat percentage was determined by means of skinfold thickness, according the Siri equation [15]. Skin folds were measured at four sites: subscapular, suprailiacal, and at the triceps and biceps [16].

\subsubsection{Protocol}

Subjects visited the climate chamber during winter (January-February 2011, average outside temperature ranged from 0.2 to $8.0^{\circ} \mathrm{C}$ [17]). During this one day visit they were exposed to, in total, four different conditions (two for this experiment (S1 and S2) and two for another related experiment). The order of the two experiments was alternated; e.g. subject 1 started with S1 and S2 in the morning and ended with the other experiment in the afternoon, subject 2 started with the other experiment in the morning and ended with S1 and S2 in the afternoon, subject 3 started with S1 and S2, etc. For practical reasons, the order of the experiments S1 and $\mathrm{S} 2$ was kept the same in all cases.

Table 2

Subject characteristics.

\begin{tabular}{lccc}
\hline & Mean \pm std. dev & Minimum & Maximum \\
\hline Age $(\mathrm{yr})$ & $23.5 \pm 1.7$ & 20 & 26 \\
Height $(\mathrm{cm})$ & $185.0 \pm 6.1$ & 177.0 & 197.0 \\
Weight $(\mathrm{kg})$ & $77.7 \pm 8.8$ & 67.5 & 91.2 \\
Body fat\% $(\%)$ & $16.8 \pm 3.9$ & 8.7 & 23.5 \\
BMI $\left(\mathrm{kg} / \mathrm{m}^{2}\right)$ & $22.6 \pm 1.6$ & 21.4 & 25.9 \\
\hline
\end{tabular}

Prior to the measurements, the subjects performed a light exercise of $5 \mathrm{~min}$ to obtain skin vasodilatation in order to ensure that all subjects entered the climate room in the same thermal state [18]. Vasodilatation was assessed by the skin temperature difference between forearm and top of the forefinger [19,20]. Furthermore, the skin temperature sensors were attached, and the subjects characteristics (height, weight, and fat percentage) were determined.

After entering the climate room, the experiment started with an acclimatization period (30 min). During this period they received an instruction regarding the use of the questionnaires. After completion of the first case an acclimatization period of $30 \mathrm{~min}$ followed (as preparation for the second case). During this period the subjects had the opportunity to visit the rest room. A detailed time line is given in Fig. 3.

During the experiments, the subjects wore standardized clothing, consisting of a cardigan, jogging pants, thin T-shirt, underpants, socks and shoes. The clo-values were determined according to McCullough et al. and NEN-EN-ISO 9920 [21-23]. The total heat resistance of the clothing ensemble, including desk chair, was approximately 1.0 clo. The subjects continuously performed office tasks; their metabolic rate was estimated to be approximately 1.2 met [14].

\subsubsection{Questionnaires}

Every $30 \mathrm{~min}$, starting at $t=0 \mathrm{~min}$, the test subjects filled in a questionnaire. Thermal sensation votes, both global and local for each body part (Fig. 2b), were asked on a continuous 7-point ASHRAE thermal sensation interval scale, where each point on the line could be marked [14,24]. Global and local thermal comfort were asked on an ISO-based 4-point thermal comfort scale ('Comfortable', 'Slightly Comfortable', 'Slightly Uncomfortable', and 'Uncomfortable') [25]. Visual analogue scales (VAS) were used to assess adverse perceptions and the perceived indoor environment [26]. A question to assess perceived stress was included as well. The questionnaires were presented to the subjects in Dutch through an Internet browser.

The differences in physical measurements were tested using ANOVA. Differences in physiological responses and subjective responses between the two experimental cases were studied using the non-parametric Wilcoxon signed-rank Test. Frequency analyses were used to indicate differences within thermal comfort votes and perceived air velocity. Significant effects are reported for $P<0.05$. The commercially available software package PASW Statistics 18.0 (SPSS Inc., Chicago, USA) was used to analyse the data.

\subsection{Results}

\subsubsection{Physical measurements}

Table 1 indicates significant $(P<0.05)$ differences in mean operative temperature, floor temperature, mean radiant temperature, and mean air velocity between case S1 and S2. In Fig. 4 the measured air temperatures and air velocities, averaged for all

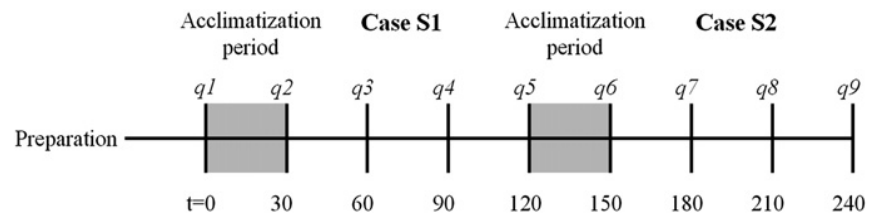

Fig. 3. Time line of measurement protocol; $\mathrm{q}$ is representing the questionnaire moments. 

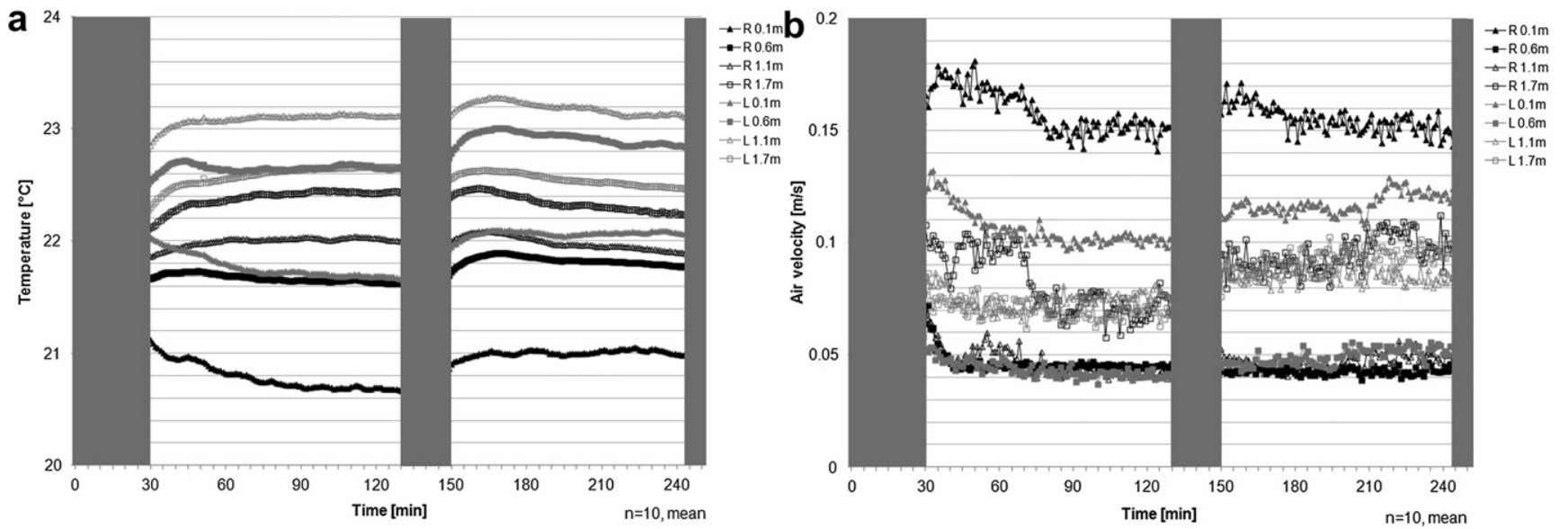

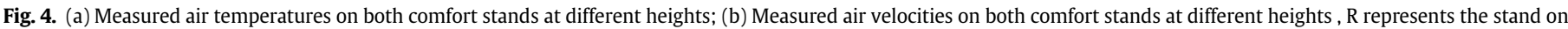
the right (cold wall) side of the subject, $L$ represents the stand on the left side and the number indicates the distance in metres from the floor.

subjects, are represented. The first $30 \mathrm{~min}$ of each case (i.e. the period from $t=0$ to $t=30$ and $t=150$ to $t=180$ ) are not presented because this period is regarded as acclimatization period where the subjects became in equilibrium. Significant differences were found at both measurement stands for the temperature gradient (along the height; mean temperature difference between the sensors at $1.7 \mathrm{~m}$ and $0.1 \mathrm{~m}$ height $)$ between case $\mathrm{S} 1\left(\Delta T=1.4 \pm 0.17^{\circ} \mathrm{C}\right)$ and $\mathrm{S} 2$ $\left(\Delta T=0.8 \pm 0.09^{\circ} \mathrm{C}\right)$. The sensor at $0.1 \mathrm{~m}$ height on the right side of the subject (closest to the cold wall) measured the lowest temperatures. During S2 this temperature raised due to the higher floor surface temperature, which caused a decrease in the temperature gradient between 0.1 and $1.7 \mathrm{~m}$ height. Both sensors closest to the floor $(0.1 \mathrm{~m}$; left and right) measured the highest air velocities and lowest temperatures. The air velocities at $0.1 \mathrm{~m}$ at the right side of the subject exceed $0.15 \mathrm{~m} / \mathrm{s}$ which, based on Equation (1), indicate downdraught during both experimental cases. The air velocities on the left side are lower in comparison to the right side, which is caused by a disruption of the flow field due to the subject. The mean radiant temperature asymmetry was in both cases $6.1^{\circ} \mathrm{C}$. According to NEN-EN-ISO 7730 [14] the percentage dissatisfied
(PD) due to a cold wall is smaller than $10 \%$, and should therefore not influence the draught perception.

\subsubsection{Physiological measurements}

Mean, distal and proximal skin temperatures, and core temperature, averaged for all subjects, are given in Fig. 5. Furthermore, the mean skin temperature of the left side (measurement sites $2,6,15,16,21,24)$ and the right side $(5,17,18,20,22,23)$ of the body are presented.

The difference in mean skin temperature between S1 and S2 is significant $\left(33.0 \pm 0.04{ }^{\circ} \mathrm{C}\right.$ vs $\left.32.9 \pm 0.08{ }^{\circ} \mathrm{C} P<0.01\right)$, although these differences were within the measurement accuracy (mean difference $0.02 \pm 0.06{ }^{\circ} \mathrm{C}$ ). Difference in distal skin temperature between S1 $\left(31.2 \pm 0.19{ }^{\circ} \mathrm{C}\right)$ and S2 $\left(30.9 \pm 0.24{ }^{\circ} \mathrm{C}\right)$ was also significant $\left(P<0.01\right.$; mean difference $\left.0.29 \pm 0.14{ }^{\circ} \mathrm{C}\right)$. Core temperature and proximal skin temperature were significant $(P<0.01)$ higher during S2 (mean difference respectively $0.10 \pm 0.06{ }^{\circ} \mathrm{C}$ and $0.10 \pm 0.10^{\circ} \mathrm{C}$ ).

During both cases the skin temperature of the right side (closest to cold wall) of the subject was significant $(P<0.01)$ lower in
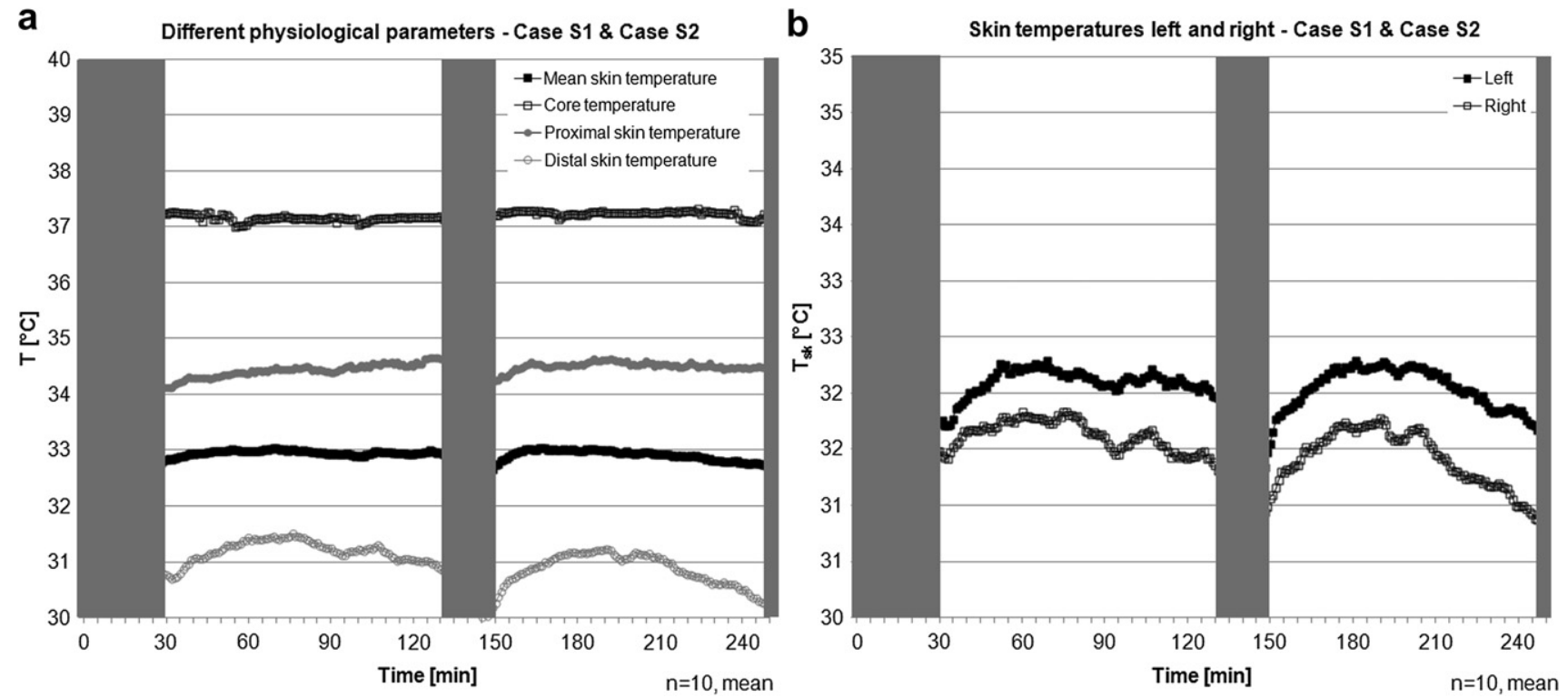

Fig. 5. (a) Measured mean, proximal and distal skin temperatures and core temperature; (b) Mean skin temperature of the left and right (cold wall) side of the body. 
comparison to the left side (mean difference S1: $0.46 \pm 0.11^{\circ} \mathrm{C}$ and S2: $0.61 \pm 0.09{ }^{\circ} \mathrm{C}$ ). The skin temperature of the right side was significant lower $(P<0.01)$ during S2 compared to S1. The skin temperature of the extremities (hands and feet) fluctuated more during both cases (range $30.5-32.5^{\circ} \mathrm{C}$ ) than the skin temperatures of the body parts close to the core (range $34-35^{\circ} \mathrm{C}$ ), to regulate the heat exchange with the environment.

The increase in skin temperature of the left and right side of the subject and distal skin temperature during the first 30 min of S2 is most probably caused by vasodilatation $\left(\Delta T_{\text {(forearm-fingertip })} \approx 0\right)$ which is indicated in Fig. 6 . During the acclimatization period prior to case S2 subjects were allowed to leave the climate chamber to visit the rest room. The increase in vasoconstriction $(t=150)$ most probably occurred because their hands were cooled due to hand washing. Furthermore, the small increase in vasodilatation $(t=180)$ can be explained by a redistribution of the blood which occurred due to a change in posture (from standing to sitting). Subsequently, the increase (from $t=210$ ) in vasoconstriction is caused by cooling of the subjects due to the sedentary activity level.

\subsubsection{Subjective responses}

The subjective responses were analysed for the last three questionnaires of each case (i.e. S1: q3-q5 and S2: q7-q9), to exclude possible effects from the acclimatization period. Mean whole-body thermal sensation (TS) during S1 (averaged for all subjects and three questionnaires) was $0.16 \pm 0.28$, mean TS during S2 was $0.07 \pm 0.47$ (all corresponding to approximately neutral). The difference in TS between both cases was not significant $(P>0.05)$. In Fig. 7 the results of the frequency analyses of wholebody thermal comfort (TC) votes and perceived air velocity are presented. The case effect on TC was not significant. However, differences in perceived air velocity were significant $(P<0.05)$, where in case S2 more often, in comparison to S1, an air movement was observed by the subjects (Fig. 7b). When the subjects registered an air movement, this air movement was mostly felt at head level.

Regarding thermal comfort of the local body parts, only the feet, lower arms and hands were on occasion slightly uncomfortable,

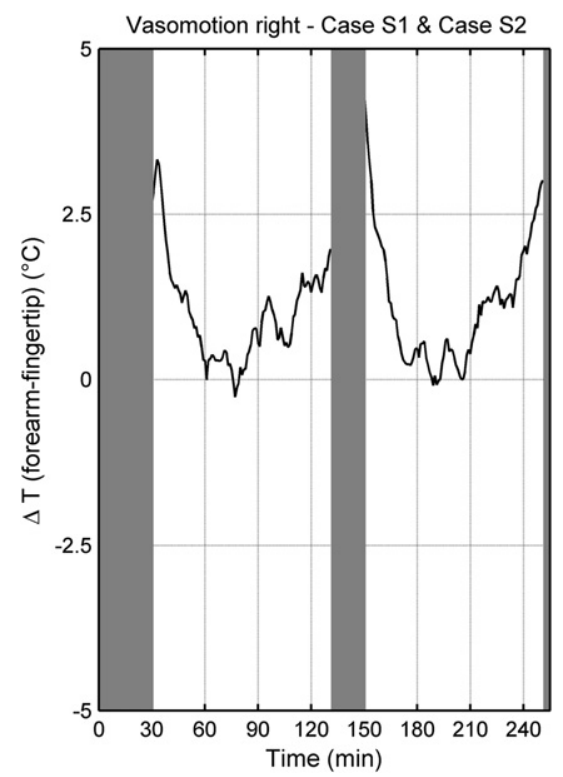

Fig. 6. Mean difference between forearm and fingertip temperature during the cases $\mathrm{S} 1$ and S2. Vasoconstriction is indicated by positive values, vasodilatation by negative values.
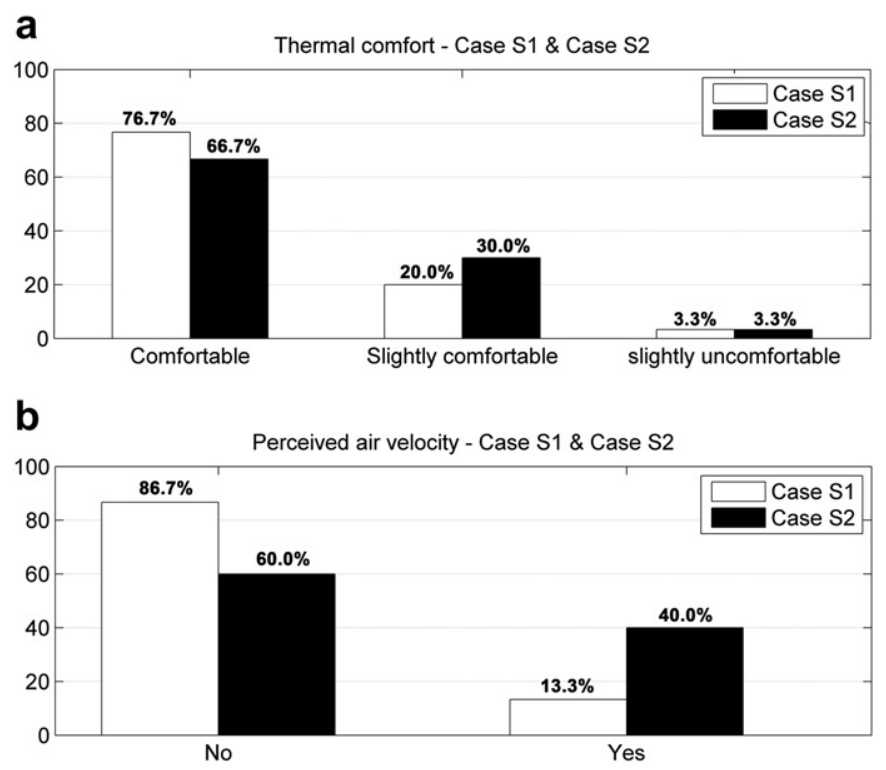

Fig. 7. Frequency results of (a) thermal comfort and (b) perceived air velocity.

however this did not significantly influence whole-body TS and TC (data not presented). Although in S2 more often an air movement was noticed (Fig. 7b), the subjects preferred no change in air movement in both cases. Furthermore, both cases (all subjects) were assessed as acceptable and no change in terms of warmer and cooler was preferred.

\subsection{Discussion human data}

To the best of our knowledge, this study is the only one wherein subjective responses were taken into account to validate the rule of thumb of Olesen [1] to predict downdraught from cold surfaces. Previous studies focussed mainly on the flow principles and possible solutions to prevent downdraught $[2,6,27]$. However, cold radiant asymmetry and stratification could be, for example, of importance as well regarding thermal comfort in relation to downdraught $[4,28]$.

The differences in realized conditions between both cases are relatively small, due to the requirements set with respect to the operative temperature. The objective of the experiments with subjects was to impose conditions which represent daily situations. Nevertheless, differences in subjective responses regarding the perceived air velocity were found between S1 and S2 (Fig. 7). However, in practice larger differences can occur which may result in larger differences between the subjective responses. Besides, the results from the physical measurements show an increased air velocity and related decreased air temperature near the floor for both experimental cases. This indicates that the subjects were exposed to downdraught during both cases. But this downdraught was not registered by the subjects. They did not report any air movement around the feet. In the cases where subjects reported air movement, this was felt at head level, despite relatively low velocities and turbulence intensities (in the range of $0.05-0.1 \mathrm{~m} / \mathrm{s}$ and $20-25 \%)$.

The results show that the skin temperature is influenced by the cold wall (mean surface temperature S1: $13.7 \pm 0.44{ }^{\circ} \mathrm{C}$ and S2: $13.0 \pm 0.56{ }^{\circ} \mathrm{C}$. Significant differences were found in physiological responses between the two cases, but no significant differences were observed for the subjective responses. In general, both conditions were assessed by the subjects as comfortable (including slightly comfortable votes). Although, effects from local body parts 
on whole-body thermal sensation and comfort were observed in Zhang et al. [29,30], no influences of local body parts on wholebody thermal sensation and comfort were observed in this study. The subjective results are in line with the comfort prediction according to NEN-EN-ISO 7730 [14]. However, following the rule of thumb [1] the conditions are not allowed because of an increased risk for uncomfortable conditions caused by downdraught.

\subsection{Conclusion subject experiments}

According to the rule of thumb both experimental conditions are not allowed with respect to an increased risk of downdraught. However, both experimental conditions were perceived as comfortable by the subjects and the subjects did not prefer a change in air movement. Furthermore, the radiant temperature asymmetry was within the comfort limits according to NEN-EN-ISO 7730 [14]. Therefore, both experimental conditions were regarded as acceptable.

\section{Numerical model development and analysis}

The subject experiments provide valuable information, but are limited regarding the number of variants that can be studied. Therefore, a variant study has been conducted to further analyse the rule of thumb which can be used to predict downdraught. To perform this study CFD has been used; for which a numerical model has been developed, this model will be discussed in the following.

\subsection{Computational geometry and discretisation}

The geometry is adopted from the climate chamber geometry, as discussed in Section 2, resulting in a computational domain with dimensions $5.4 \times 3.6 \times 2.7 \mathrm{~m}^{3}(\mathrm{~L} \times \mathrm{W} \times \mathrm{H}$, Fig. 8a). With respect to the discretisation two types of grid have been developed: (1) a hybrid grid (1.4 million cells, Fig. 8b) for the model with human being (dimensions based on thermal manikin used for validation), combining both tetrahedral and hexahedral cells and (2) a structured grid ( 0.5 million cells, Fig. $8 \mathrm{c}$ ) for an empty climate chamber. The latter model was developed to allow extension of the number of cases that could be investigated (e.g. geometries with different room heights). Additional models have been developed from these two types of grid for sensitivity analysis. All grids were generated using the commercially available software Gambit 2.4.6 (Ansys Inc, Canonsburg, USA).

\subsection{Boundary conditions and solver settings}

The commercially available software package Ansys Fluent 12.1.4 (Ansys Inc., Canonsburg, USA) has been used to solve the transient 3D Reynolds-averaged Navier Stokes (RANS) equations in combination with the Renormalisation Group (RNG) $k-\varepsilon$ turbulence model [31] using enhanced wall treatment (average $\mathrm{y}^{+}$value cold wall: 10 [coarse grid], 5 [fine grid] [32]). Stamou et al. have shown that by using this turbulence model accurate results can be obtained for the prediction of indoor air flow [33]. Buoyancy forces are modelled through the Boussinesq approximation.

The SIMPLE algorithm is used for pressure-velocity coupling, for pressure interpolation the body force weighted discretisation scheme is used and second order discretisation schemes are used for both the convection terms and viscous terms of the governing equations following the best practice guidelines [34]. Simulations have been performed with a time step of $1 \mathrm{~s}$. Per time step 10 iterations were performed. In total 2700 time steps (45 min real time) were simulated. Convergence criterion for the scaled residuals was $10^{-5}$. Furthermore, the achievement of a heat balance was an important criterion for acceptance of the solution. Despite the fact that steady state conditions were provided, the results of the simulation showed a transient (periodic) behaviour. This transient a

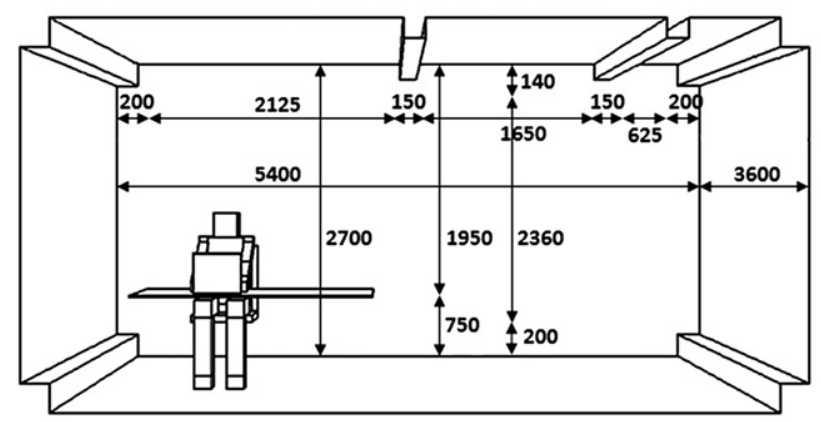

C

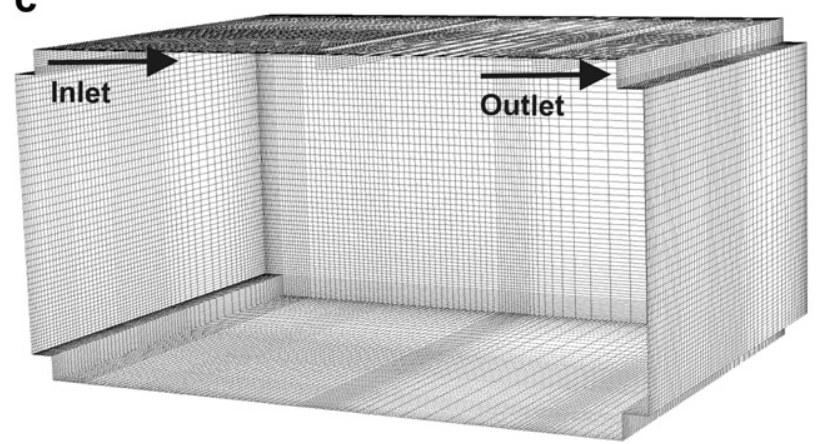

b

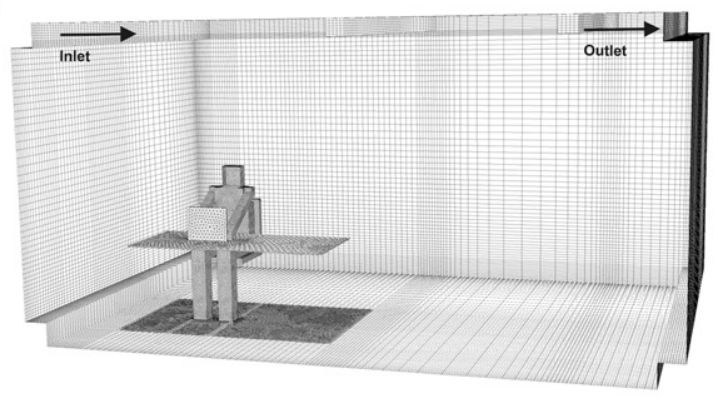

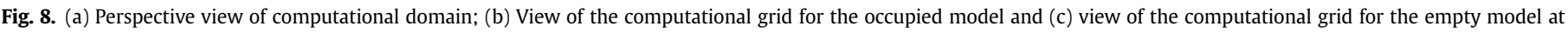
some of the domain surfaces. 
Table 3

Boundary conditions for initial numerical models.

\begin{tabular}{llc} 
& Case M1 & Case M2 \\
\hline Inlet - air temperature $\left[{ }^{\circ} \mathrm{C}\right]$ & 22.0 & 22.0 \\
Inlet - air velocity [m/s] & 1.0 & 1.0 \\
Inlet - turbulence intensity [\%] & 7 & 7 \\
Inlet - turbulence length scale [m] & 0.0014 & 0.0014 \\
Surface temperature east wall $\left[{ }^{\circ} \mathrm{C}\right]$ & 13.8 & 13.4 \\
Surface temperature north wall $\left[{ }^{\circ} \mathrm{C}\right]$ & 23.1 & 22.7 \\
Surface temperature south wall $\left[{ }^{\circ} \mathrm{C}\right]$ & 23.2 & 22.7 \\
Surface temperature west wall $\left[{ }^{\circ} \mathrm{C}\right]$ & 23.2 & 22.8 \\
Surface temperature floor $\left[{ }^{\circ} \mathrm{C}\right]$ & 23.0 & 24.3 \\
Surface temperature ceiling $\left[{ }^{\circ} \mathrm{C}\right]$ & 23.3 & 22.9 \\
\hline
\end{tabular}

behaviour could not be referred back to the grid and solver settings. Instead the behaviour is explained by the geometrical and flow configuration which allows for flow instability. In the results, data from the last $900 \mathrm{~s}$ are averaged and completed with the standard deviation over that period.

During the simulations radiation was not taken into account, only the convective part was solved. To compensate for the radiation part the heat emission of the human being has been halved. Furthermore, the surface temperatures were fixed. The heat emission of the human being, in case of the empty model, is taken into account by implementing a User Defined Function (UDF). The boundary conditions for the initial models were adopted from the subject conditions (Table 1) and measured for a room with a thermal manikin (M1 and M2). The averaged measurement results for both cases, which have been used as boundary conditions, are given in Table 3.

\subsection{Model analysis}

As part of the model analysis, a comparison was made between measurement and simulation results for the different type of grids (occupied chamber and empty chamber). These results are presented in Fig. 9a and b. The comparison is shown for Case M2 (Table 3), for the air temperature and air velocity along the height of the comfort stand at the right side of the subject. At this position conditions for downdraught are assumed worst. The results for the structured grid of the empty room (with UDF) show improved agreement with the measurements compared to the hybrid grid with manikin for both air velocity (mean deviation 4\% and 20\% respectively) and air temperature ( $0.2 \%$ and $1.5 \%$ respectively). For air velocity, both grids predict the trend. Based on this comparison the variant study is conducted with the grid of the empty room.

Results for a limited grid sensitivity analysis for the empty room grid are shown in Fig. 9c and d. Results again are shown for the most critical location with respect to downdraught. The finer grid has a double amount of cells (1.1 million cells). Following this experimental and grid sensitivity analysis the coarse grid is retained for further analysis.

\section{Variant study}

The subject experiments were confined within a fixed geometry and boundary conditions. Therefore a numerical variant study has been conducted to analyse the rule of thumb for downdraught analysis outside these constraints. The developed numerical model has been used for this study.

Jurelionis et al. show that higher windows cause more downdraught [35]. In existing downdraught studies, however, the window height is limited to $3 \mathrm{~m}$. Furthermore, the effect of downdraught is larger in case of a larger temperature difference between the room air and window surface [2]. Finally, the experimental results presented indicate an effect of the floor temperature on downdraught. Therefore, different floor temperatures, corresponding to low temperature heating systems, have been studied as well. In addition, a distinction has been made in a proportional
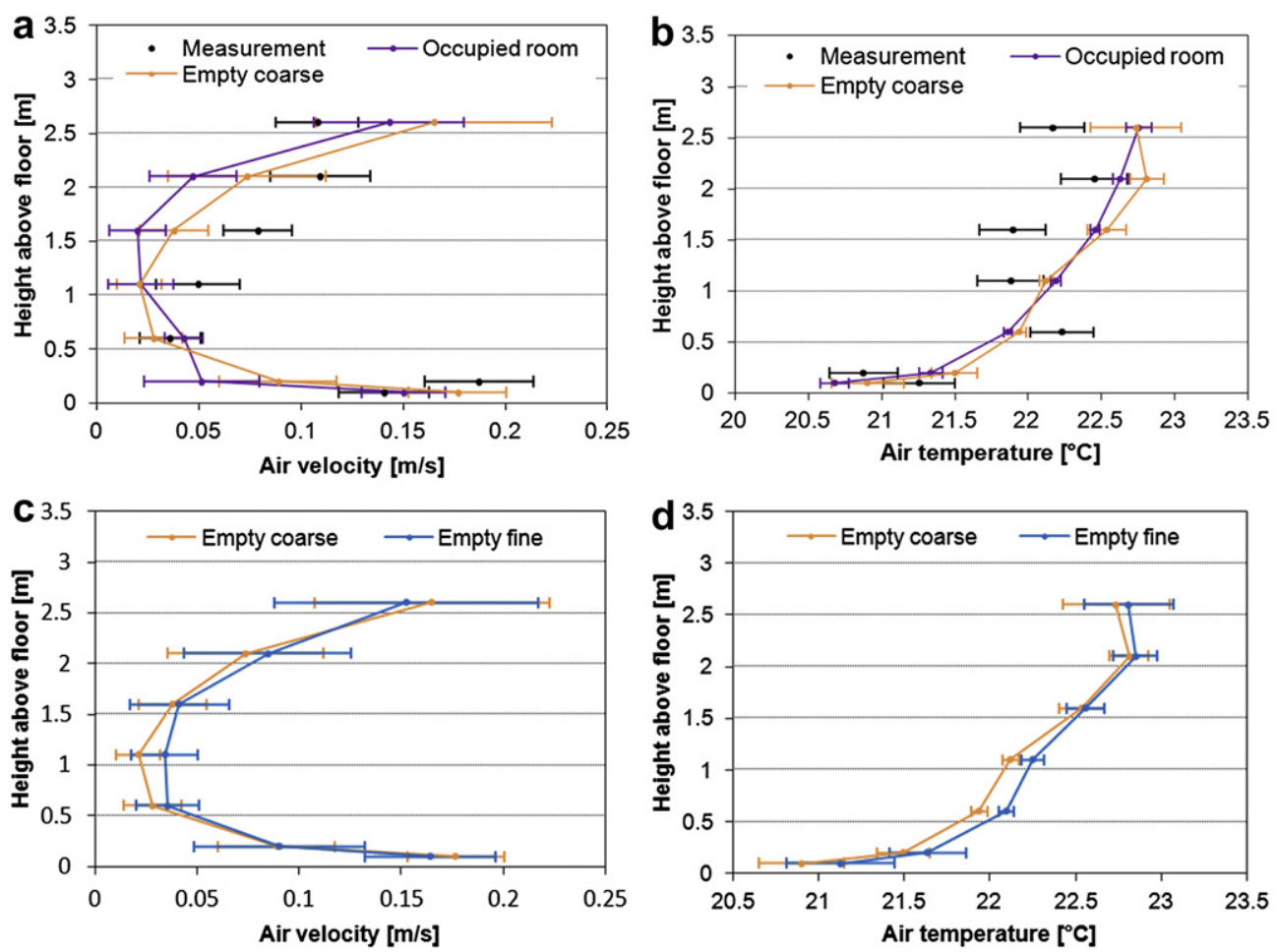

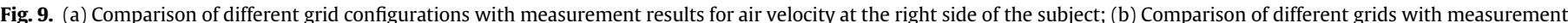

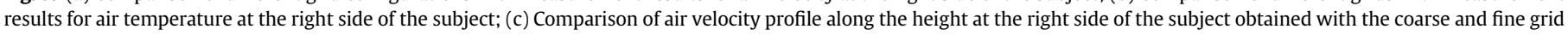
and (d) Comparison of air temperature profile along the height at the right side of the subject obtained with the coarse and fine grid. 
Table 4

Overview of different variants.

\begin{tabular}{|c|c|c|c|c|c|c|}
\hline Variant & $\begin{array}{l}\text { Room dimensions } \\
\left(\mathrm{L} \times \mathrm{W} \times \mathrm{H}^{*}\right)\end{array}$ & $\begin{array}{l}\text { Window } \\
\text { height }\end{array}$ & $\begin{array}{l}\text { Window } \\
\text { temperature }\end{array}$ & $\begin{array}{l}\text { Floor } \\
\text { temperature }\end{array}$ & $\begin{array}{l}\text { Wall } \\
\text { temperature }\end{array}$ & $\begin{array}{l}\text { Operative } \\
\text { temperature }\end{array}$ \\
\hline$\overline{C 1}$ & $5.4 \times 3.6 \times 2.7 \mathrm{~m}^{3}$ & $2.7 \mathrm{~m}$ & $13^{\circ} \mathrm{C}$ & $26.0^{\circ} \mathrm{C}$ & $19.6{ }^{\circ} \mathrm{C}$ & $21.5^{\circ} \mathrm{C}$ \\
\hline $\mathrm{C} 2$ & $5.4 \times 3.6 \times 2.7 \mathrm{~m}^{3}$ & $2.7 \mathrm{~m}$ & $13^{\circ} \mathrm{C}$ & $21.0^{\circ} \mathrm{C}$ & $23.0^{\circ} \mathrm{C}$ & $21.0^{\circ} \mathrm{C}$ \\
\hline V1 & $5.4 \times 3.6 \times 5.4 \mathrm{~m}^{3}$ & $5.4 \mathrm{~m}$ & $19^{\circ} \mathrm{C}$ & $21.0^{\circ} \mathrm{C}$ & $21.6^{\circ} \mathrm{C}$ & $21.0^{\circ} \mathrm{C}$ \\
\hline V2 & $5.4 \times 3.6 \times 5.4 \mathrm{~m}^{3}$ & $5.4 \mathrm{~m}$ & $16{ }^{\circ} \mathrm{C}$ & $26.0^{\circ} \mathrm{C}$ & $20.3^{\circ} \mathrm{C}$ & $21.5^{\circ} \mathrm{C}$ \\
\hline V3 & $5.4 \times 3.6 \times 5.4 \mathrm{~m}^{3}$ & $5.4 \mathrm{~m}$ & $16^{\circ} \mathrm{C}$ & $21.0^{\circ} \mathrm{C}$ & $22.4^{\circ} \mathrm{C}$ & $21.0^{\circ} \mathrm{C}$ \\
\hline V4 & $5.4 \times 3.6 \times 5.4 \mathrm{~m}^{3}$ & $5.4 \mathrm{~m}$ & $13^{\circ} \mathrm{C}$ & $26.0^{\circ} \mathrm{C}$ & $20.8^{\circ} \mathrm{C}$ & $21.5^{\circ} \mathrm{C}$ \\
\hline V5 & $5.4 \times 3.6 \times 5.4 \mathrm{~m}^{3}$ & $5.4 \mathrm{~m}$ & $13^{\circ} \mathrm{C}$ & $21.0^{\circ} \mathrm{C}$ & $23.2{ }^{\circ} \mathrm{C}$ & $21.0^{\circ} \mathrm{C}$ \\
\hline V6 & $5.4 \times 3.6 \times 5.4 \mathrm{~m}^{3}$ & $5.4 \mathrm{~m}$ & $13^{\circ} \mathrm{C}$ & $26^{\circ} \mathrm{C}+30^{\circ} \mathrm{C}$ & $20.6{ }^{\circ} \mathrm{C}$ & $22.0^{\circ} \mathrm{C}$ \\
\hline V7 & $5.4 \times 3.6 \times 8.1 \mathrm{~m}^{3}$ & $8.1 \mathrm{~m}$ & $13^{\circ} \mathrm{C}$ & $21.0^{\circ} \mathrm{C}$ & $23.3^{\circ} \mathrm{C}$ & $21.0^{\circ} \mathrm{C}$ \\
\hline
\end{tabular}

$* P<0.05$.

distributed floor heating system and a local (near the window) denser floor heating system. The geometry of the climate chamber serves as basis for all models; the height has been increased for different variants, resulting in two additional configurations $(5.4 \mathrm{~m}$ and $8.1 \mathrm{~m}$ height) with respectively 0.8 and 1.1 million cells.

\subsection{Variants}

In total 8 variants have been studied (Table 4), applying window height, window temperature and floor temperature as variables. Case M2 is used for the validation of the numerical model (Section 4). Wall temperatures have been defined to arrive at (nearly) similar winter indoor operative temperatures.

\subsection{Results}

Fig. 10a and b indicate the positions for which results are presented and compared. Comparison is done for window height, window temperature and floor temperature.

The velocity magnitude along the height and width is significantly $(P<0.01)$ influenced by the window height (variant $\mathrm{C} 2$, V5 and V7). Largest increase in velocity is found near the floor (Fig. 11a) at the interface of the living zone (distance to window: $1 \mathrm{~m}$ ). The temperature of the window significantly $(P<0.01)$ influenced both velocity magnitude and air temperature distribution along the height and width of the room. Largest increase in both air velocity and air temperature (Fig. 11b) were found near the floor as well. An increase in floor temperature (Fig. 11c) caused a significant $(P<0.01)$ increase in air velocity near the floor for both an equally distributed floor temperature (V4) and a local (near the window) warmer floor temperature (V6). In comparison to a floor temperature of $21{ }^{\circ} \mathrm{C}$ (V5) the air velocity increases up to a maximum average air velocity near the floor of $0.31 \mathrm{~m} / \mathrm{s}$ in variant V6. Note that in this case again flow instability was observed in the transient simulation results. The average air velocities over the height of the room (from $0.5 \mathrm{~m})$ do not differ significantly $(P>0.05)$ for the different floor temperatures.

\subsubsection{Thermal comfort}

Thermal comfort level is assessed using NEN-EN-ISO 7730 [14]. The whole body thermal sensation indices are calculated [Predicted Mean vote (PMV) and Predicted Percentage Dissatisfied (PPD)], as well as the predicted percentage dissatisfied (PD) due to local discomfort (caused by respectively draught (DR), a temperature gradient, a relative high floor temperature and radiant asymmetry). The results for the different indices are presented in Table 5. Fig. 12 visualizes the draught rate for cross section $\mathrm{AA}^{\prime}$ (Fig. 11a) for variant V4 (floor temperature is $26^{\circ} \mathrm{C}$ ) and V5 (floor temperature is $21^{\circ} \mathrm{C}$ ). The results indicate that highest draught rates are present near the floor and are higher for a higher floor temperature.

\subsubsection{Applicability rule of thumb}

Whether the variants are allowed according to the rule of thumb of Olesen [1] is presented in Table 6, the variants are assessed for a maximum allowed air velocity of $0.18 \mathrm{~m} / \mathrm{s}$. The $U$-value of the glass ( $\left.U_{\text {glass }}\right)$ is calculated according to Equation (3). Based on the rule of thumb, only variant V1 (with a window temperature of $19^{\circ} \mathrm{C}$ ) will not present a downdraught risk. Furthermore, the rule of thumb assumes lower values for the variants with floor heating. This indicates less risk on downdraught compared to variants without floor heating. The air velocity and draught rate in the variants with floor heating however are higher.

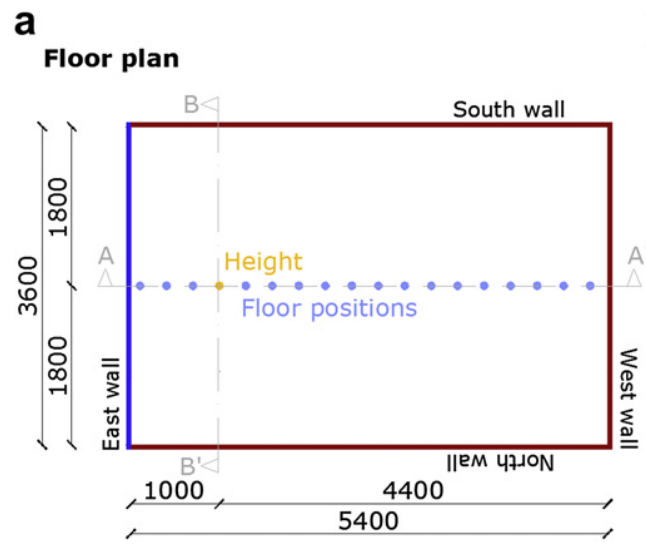

b cross section AA'

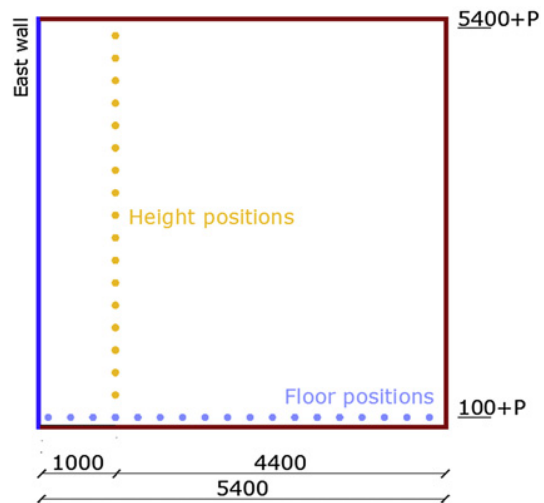

Fig. 10. Different positions for which the variants are compared (a) floor plan and (b) cross section $\mathrm{AA}^{\prime}$. 
a

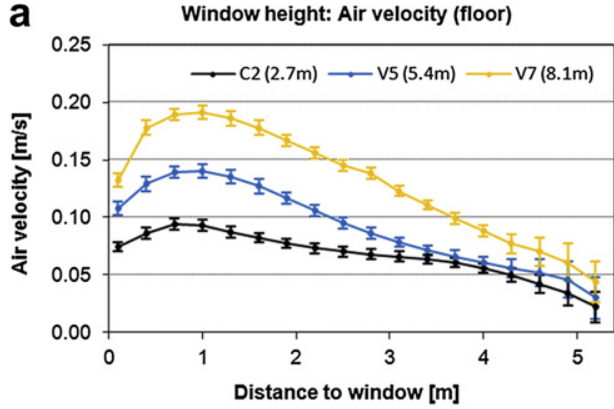

C

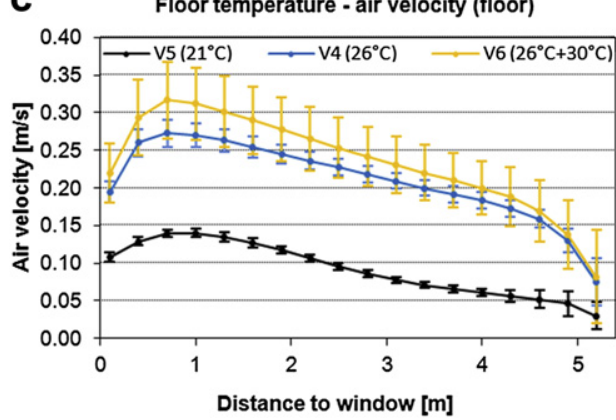

b

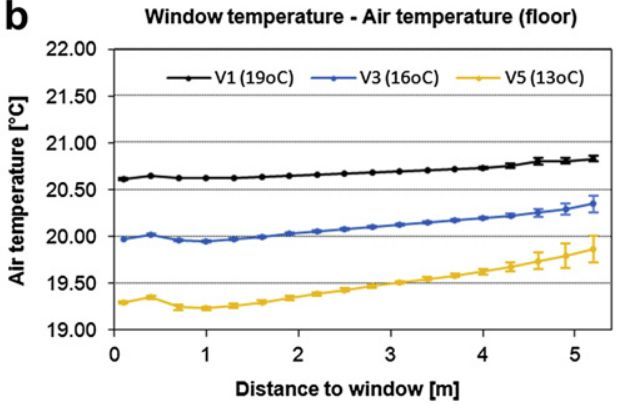

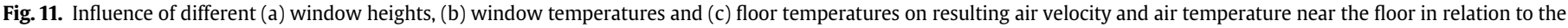
distance to the window.

\subsection{Discussion on variant study}

The numerical results show fluctuations in air temperature and air velocity, indicated by the error bars in the results, due to a timedependent flow pattern. These fluctuations were observed in both cases (C1 and C2) and all variants (V1-V7). According to Rees et al. complex quasi periodic fluctuations can occur under stationary boundary conditions [36]. However, the measurement period per measurement position ( $5 \mathrm{~min}$ ) for the calibration measurements was too short to capture one whole period of the fluctuation. Nevertheless, as the trend is predicted well and mean deviations are limited it is concluded that the model is valid to perform a variant study.

The results from the variant study confirm the results of previous studies on downdraught (e.g. [35,37]) that window height and window temperature significantly influence downdraught. Although Huizenga et al. [4] concluded that cold radiant asymmetry can cause discomfort, based on the presented numerical results discomfort due to radiant asymmetry was

Table 5

Results of global and local thermal comfort indices for the different variants, PMV represents predicted mean vote, PPD represents predicted percentage dissatisfied and PD represents percentage dissatisfied.

\begin{tabular}{lllllll}
\hline Variant & PMV $^{\mathrm{a}}[-]$ & $\mathrm{PPD}^{\mathrm{a}}[\%]$ & $\begin{array}{l}\mathrm{PD}^{\mathrm{a}} \text { draught } \\
\text { rate [\%] }\end{array}$ & $\begin{array}{l}\mathrm{PD}^{\mathrm{a}} \text { Temp. } \\
\text { gradient [\%] }\end{array}$ & $\begin{array}{l}\mathrm{PD}^{\mathrm{a}} \text { floor } \\
\text { temp. [\%] }\end{array}$ & $\begin{array}{l}\mathrm{PD}^{\mathrm{a}} \text { radiant } \\
\text { asymm. [\%] }\end{array}$ \\
\hline C1 & 0.27 & 5.2 & 5.0 & 0.2 & 6.8 & 0.8 \\
C2 & 0.38 & 5.4 & 0.0 & 0.1 & 7.1 & 1.1 \\
V1 & 0.42 & 5.5 & 0.0 & 0.2 & 7.1 & 0.2 \\
V2 & 0.32 & 5.2 & 4.9 & 0.2 & 6.8 & 0.5 \\
V3 & 0.37 & 5.3 & 0.0 & 0.2 & 7.1 & 0.6 \\
V4 & 0.26 & 5.2 & 6.1 & 0.1 & 6.8 & 1.0 \\
V5 & 0.31 & 5.2 & 2.4 & 0.1 & 7.1 & 1.3 \\
V6 & 0.33 & 5.3 & 7.0 & 0.1 & 6.8 & 0.7 \\
V7 & 0.29 & 5.2 & 3.7 & 0.1 & 7.1 & 1.3 \\
\hline
\end{tabular}

a Values are presented as mean. assessed low in the variant study when applying NEN-EN-ISO 7730 [14] (Table 5).

To the best of our knowledge, no studies on downdraught have included floor temperature as significant influencing parameter. Yet, the numerical results show that floor temperature influences the air flow pattern negatively with respect to downdraught. The warmer floor $\left(+5^{\circ} \mathrm{C}\right)$ caused the maximum air velocity to increase by a factor two close to the floor due to buoyant forces. It should be marked that the floor heating variants have wall temperatures lower than room air temperature (max. $\Delta T$ of $0.9{ }^{\circ} \mathrm{C}$ ) and the variants with a floor of $21.0^{\circ} \mathrm{C}$ have warmer walls compared to the room air ( $\max . \Delta T=2.5^{\circ} \mathrm{C}$ ). This was necessary to achieve and maintain similar operative temperatures. In spite of this difference, the colder walls (compared to the air temperature) did not result in additional downdraught, the air flow near these walls is still upwards. However, the wall temperature can influence the air flow in the rest of the room. The effect of floor heating on air flow was confirmed by the measurement results. However, during the measurements these differences were relatively small but significant $\left(23.0{ }^{\circ} \mathrm{C}\right.$ versus $24.3{ }^{\circ} \mathrm{C}$ for case S1 and S2 respectively). It is recommended to validate these results further with experimental measurements.
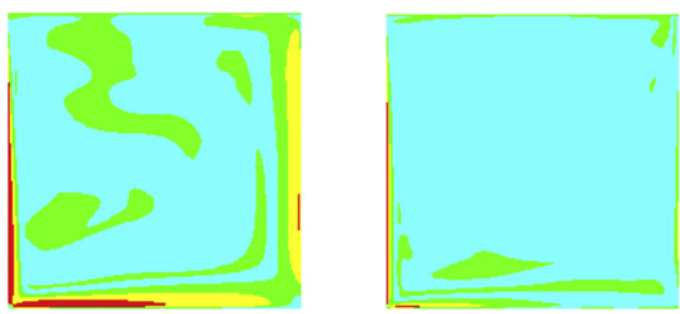

Fig. 12. Draught rates on cross section $A A^{\prime}$; left: V4 (floor temperature $26{ }^{\circ} \mathrm{C}$ ) and right: V5 (floor temperature $21^{\circ} \mathrm{C}$ ). 
Table 6

Assessment of variants using the rule of thumb of Olesen [1].

\begin{tabular}{lcl}
\hline Variant & $U_{\text {glass }}{ }^{*} h[-]$ & Allowed \\
\hline C1 & 4.9 & No \\
C2 & 5.3 & No \\
V1 & 2.7 & Yes \\
V2 & 6.0 & No \\
V3 & 6.6 & No \\
V4 & 9.5 & No \\
V5 & 10.4 & No \\
V6 & 9.7 & No \\
V7 & 15.6 & No \\
\hline
\end{tabular}

\section{Discussion on applicability of a rule of thumb to prevent downdraught}

Compared to the NEN-EN-ISO 7730 [14] guidelines, as applied to the investigated numerical variant, the rule of thumb is conservative. All but one case (variant V1) are regarded as downdraught risk, based on the rule of thumb of Olesen [1]. This is because the maximum occurring air velocity is higher than $0.15 \mathrm{~m} / \mathrm{s}$ in most variants. However, this maximum value occurs within one meter from the window at floor level (i.e. outside the living area, Fig. 1d) and decreases rapidly. When the maximum occurring Draught Rate (DR) is considered, the same design conclusions are obtained as with the rule of thumb. Only Numerical variant 1 (V1) with $19{ }^{\circ} \mathrm{C}$ window temperature is assessed as acceptable (maximum $\mathrm{DR}<20 \%$ ). When including the obtained results from the subject experiments in the discussion (S1 and S2 in line with M1 and M2), the rule of thumb and DR seem to be too conservative since according to the rule of thumb the conditions would not be allowed. However, the subjective responses indicate no thermal discomfort.

It should be noticed that DR is developed for draught at neck level and, based on the results obtained, overestimates the Percentage Dissatisfied (PD) due to draught at foot level. DR should differentiate in the location where draught is expected.

Finally, the rule of thumb and the maximum DR show a different trend. Considering the rule of thumb, the temperature difference between the room air and window decreases with floor heating (for the variants) which assumed a lower maximum air velocity and thus more comfortable conditions. However, DR predicts a higher PD for the floor heating variants as a result of the increased velocity at floor level. Therefore the authors recommend to further study the effect of floor heating on downdraught and perhaps include the floor temperature as influencing parameter in the rule of thumb.

\section{Conclusions}

Based on both experimental and numerical results the rule of thumb for assessing the risk of downdraught [1], often used by engineers in practice, is conservative for the investigated experimental cases. This results in unnecessary measures to prevent the expected downdraught. Furthermore, the numerical results reveal that an increased floor temperature (i.e. floor heating) can negatively influence the air flow pattern, which results in more downdraught. Therefore, it is recommenced to implement the floor temperature as influencing parameter in the rule of thumb and to study the allowed comfort limits.

Further research should focus on comfort assessment at ankle level under downdraught configurations, for example a Percentage Dissatisfied due to draught at ankle level instead of a PD at neck level.
Finally, more research is needed regarding the instability which can occur in the indoor air velocity pattern and the influence on thermal comfort.

\section{Acknowledgements}

The financial contributions, of Agentschap NL (EOS-LT02003) and the KenWIB project are gratefully acknowledged. Appreciation is also expressed to the staff of the laboratory of the Unit Building Physics and Services (BPS) of Eindhoven University of Technology for their valuable assistance for both the experimental and numerical facilities. Furthermore, the authors express their gratitude to the participants in the experiments.

\section{References}

[1] Olesen BW. Vereinfachte methode zur vorausberechnung des thermischen raumklimas. Heizung Lueftung/Klima Haustechnik 1995;46:219-25.

[2] Heiselberg P. Draft risk from cold vertical surfaces. Build Environ 1994;29: 297-301.

[3] Ge H, Fazio P. Experimental investigation of cold draft induced by two different types of glazing panels in metal curtain walls. Build Environ 2004; 39:115-25.

[4] Huizenga C, Zhang H, Mattelaer P, Yu T, Arens E. Window performance for human thermal comfort. University of California; 2006.

[5] Larsson U, Moshfegh B. Experimental investigation of downdraught from well-insulated windows. Build Environ 2002;37:1073-82.

[6] Rueegg T, Dorer V, Steinemann U. Must cold air down draughts be compensated when using highly insulating windows? Energ Buildings 2001;33: 489-93.

[7] Larsson U, Moshfegh B, Sandberg M. Thermal analysis of super insulated windows (numerical and experimental investigations). Energ Buildings 1999; 29:121-8.

[8] den Boer TLJ, Zeiler W. Transparantie en façade. TVVL Mag 1998;37:4-13.

[9] Schellen L, Loomans MGLC, Van Marken Lichtenbelt WD, Frijns AJH, De Wit $\mathrm{MH}$. Assessment of thermal comfort in relation to applied low exergy systems - the design of a climate chamber and the use of a thermophysiological model Windsor 2010: adapting to change: new thinking on comfort London; 2010.

[10] Loomans MGLC. The measurement and simulation of indoor air flow. EIndhoven: Eindhoven University of Technology; 1998.

[11] NEN-EN-ISO 7726. Ergonomics of the thermal environment - instruments for measuring physical quantities. International Standards Organization; 2001.

[12] NEN-EN-ISO 9886. Ergonomics - evaluation of thermal strain by physiological measurements. International Standards Organization; 2004

[13] van Marken Lichtenbelt WD, Daanen HAM, Wouters L, Fronczek R, Raymann RJEM, Severens NMW, et al. Evaluation of wireless determination of skin temperature using ibuttons. Physiol Behav 2006;88:489-97.

[14] NEN-EN-ISO 7730. Ergonomics of the thermal environment - analytical determination and interpretation of thermal comfort using calculation of the PMV and PPD indices and local thermal comfort criteria. International Standards Organization; 2005.

[15] Durnin JV, Rahaman MM. The assessment of the amount of fat in the human body from measurements of skinfold thickness. Br J Nutr 1967;21:681-9.

[16] Lohman TG, Roche AF, Martorell R. Anthropometric standardization reference manual. Champaign; 1988.

[17] KNMI. Maandoverzicht van het weer in Nederland; 2011.

[18] Kingma B, Frijns A, Van Marken Lichtenbelt W. The thermoneutral zone: implications for metabolic studies. Front Biosci 2012;E4:1975-85.

[19] House JR, Tipton MJ. Using skin temperature gradients or skin heat flux measurements to determine thresholds of vasoconstriction and vasodilatation. Eur J Appl Physiol 2002;88:141-5.

[20] Sessler DI. Skin-temperature gradients are a validated measure of fingertip perfusion. Eur J Appl Physiol 2003;89:401-2. author reply 3-4.

[21] Mccullough EA, Jones BW, Tamura T. A database for determining the evaporative resistance of clothing. ASHRAE Trans 1989;95:13.

[22] Mccullough EA, Olesen BW, Hong S. Thermal insulation provided by chairs. ASHRAE Trans 1994;100:8.

[23] NEN-EN-ISO 9920. Ergonomics of the thermal environment - estimation of thermal insulation and water vapour resistance of a clothing ensemble. International Standards Organization; 2009.

[24] ASHRAE. Standard 55: thermal environmental conditions for human occupancy; 2010.

[25] NEN-EN-ISO 10551. Ergonomics of the thermal environment - assessment of the influence of the thermal environment using subjective judgement scales. International Standards Organization; 1995.

[26] Kildeso J, Wyon D, Skov T, Schneider T. Visual analogue scales for detecting changes in symptoms of the sick building syndrome in an intervention study. Scand J Work Env Hea 1999;25:361-7. 
[27] Heiselberg P, Overby H, Bjorn E. Energy-efficient measures to avoid downdraft from large glazed facades. Ashrae Tran 1995;101:1127-35.

[28] Zhang H, Huizenga C, Arens E, Yu T. Modeling thermal comfort in stratified environments. In: the 10th International Conference on Indoor Air Quality and Climate. Beijing, China; 2005.

[29] Zhang H, Arens E, Huizenga C, Han T. Thermal sensation and comfort models for non-uniform and transient environments: part I: local sensation of individual body parts. Build Environ 2010;45:380-8.

[30] Zhang H, Arens E, Huizenga C, Han T. Thermal sensation and comfort models for non-uniform and transient environments, part II: local comfort of individual body parts. Build Environ 2010;45:389-98.

[31] Yakhot V, Orszag SA, Thangam S, Gatski TB, Speziale CG. Development of turbulence models for shear flows by a double expansion technique. Phys Fluids A-Fluid 1992;4:1510-20.
[32] Loomans MGLC. Grid dependency of wall heat transfer for simulation of natural convection flow problems. Helsinki, Finland: Roomvent; 2007.

[33] Stamou A, Katsiris I. Verification of a CFD model for indoor airflow and heat transfer. Build Environ 2006;41:1171-81.

[34] European Research Community On FLow TAC. Quality and Trust in Industrial CDF - best practice guidelines. In: Casey M, Wintergerste T, editors. 1.0 ed.: Fluid Dynamics Laboratory. p. 200.

[35] Jurelionis A, Isevicius E. Cfd predictions of indoor air movement induced by cold window surfaces. J Civ Eng Manag 2008;14:29-38.

[36] Rees SJ, McGuirk JJ, Haves P. Numerical investigation of transient buoyant flow in a room with a displacement ventilation and chilled ceiling system. Int J Heat Mass Tran 2001;44:3067-80.

[37] Manz H, Frank T. Analysis of thermal comfort near cold vertical surfaces by means of computational fluid dynamics. Indoor Built Environ 2004;13:233-42. 